\title{
Cui bono, SEU CUI PRODEST?
}

\section{MONOK IsTVÁN}

A címben megfogalmazott két kérdés jogi értelmezéséhez ragaszkodva biztosan tautológia, vagyis kétszer kérdezzük meg ugyanazt, hol Cicero, hol Seneca szavait használva. Ha azonban következetesen valljuk azt az alapelvet - amelyet a mindennapi gyakorlatban követésre méltónak tartok -, hogy nem minden legitim, ami legális, ám minden, ami legitim legalizálásra érdemes, akkor a kétféle kérdésfeltevés már indokolható. Magam számára a legitimitást tartom vezérfonalnak. A nyílt tudomány kérdéskörében jól megfogható a különbség a kétféleképpen (legitim/ legális) elfogadott cselekvések közt.

A nyílt hozzáférés apostolai abból az alapelvből indulnak ki, ami ajánlások szintjén még az Európai Unió hivatalosságának is része, nevesen: amely kutatási eredmény létrejöttét közpénzből finanszírozták, nem lehet nem nyílt hozzáféréssel közzétenni. Ezzel együtt teljesen magától értetődő, hogy a rögzített (szerzői, kiadói) jogokat nem sértheti ez a közzététel, és különösen is hangsúlyosan figyelni kell arra is, hogy a közzétevő magánvállalkozásoknak a nyilvánosságra hozatal nem okozhat erkölcsi, vagy pénzügyi veszteséget. De ha gondolkodásunkat a nyílt tudományról ebben az irányban indítjuk el, akkor alapvetően a legalitás oldalán maradva töprengünk. Számomra azonban fontosabb a legitim oldal.

A könyvtörténeti szakirodalomban az információs technológiák változásáról, fordulópontjairól többféle értelemzés olvasható. Mi volt a célja azoknak, akik kitalálták az exemplar és pecia rendszert a kéziratos könyvkiadásban? Mi Gutenbergnek akkor, amikor a mozgatható betűkkel történő szedés alapján való sokszorosítást kitalálta? A célok közt elsőként felsorolandó, hogy minél többen, minél könnyebben, minél több szöveghez jussanak hozzá. És mindig ott van az is, hogy a stationarius kapjon adókedvezményt, hiszen plusz kötelmeket vállalt (ami üzleti mozgásterét csökkenti), és az, hogy minden könyv 
megszületéséhez kell a mecénás is. Igen, a Gutenberg galaxis sikerét, azt, hogy az európai gondolkodás jelentôs újító kapacitáshoz jutott, egy vállalkozói csoport, a nyomdászok és alkalmazottjaik biztosították. A nyomdászok haszon-érdekeltsége (ez még nem profitszomj, pláne nem extraprofit-szomj) számos olyan újítást eredményezett, amitől az olvasás és a könyvhasználat hatékonyabbá vált (anyanyelvűség, képi illusztrációk, címlap, szövegtagolás, mutatók stb.).

Aztán a nyomdász mellett megjelent a kiadó, aztán különvált a kereskedői világ, és már a XVII. században tudunk olyan tudományos (orvosi) könyvkiadóról, amelynek tulajdonosáról többen állítják, hogy analfabéta volt. Aztán a fia már privilégiumokat szerzett, unokája és dédunokája pedig a legrangosabb kiadó lett Párizsban (Houry). Ezzel arra utalok, hogy a könyvkiadásban megjelent a befektető, aki nem könyvet akar kiadni, nem tudományos információkat akar másokkal megosztani, hanem elsődlegesen a meglévő pénzét kívánja szaporítani. Befektetésével azonban segítheti magát az eredeti célkitüzést is. Napjainkra a folyamat ott tart - remélem ezt fejlődésnek senki nem gondolja -, hogy a tudományos információ olyan áru, mint a kőolaj ráadásul éppen nagyobb hasznot is hoz az árusítása.

A nyílt hozzáférést tehát nehezített környezetben kell megvalósítani: jó az Open Access annak, aki éppen szabadon hozzáfér. Sajnos ugyanannak akkor, amikor a saját kutatási eredményéről van szó, már nem magától értetődően jó ugyanez. Ezzel az ellentmondással arra utalok, hogy nincsen a kérdésnek sem gordioszi, sem huszáros megoldása. Az egyik elfed valós ellentmondásokat, és hosszabb távon nem konfliktusmentes rendszer áll elő, a másik meg valószínűsíthetően komoly károkat is okozna a rendszerben a virtus megmutatásának értékét nem tagadva. Vagyis a tudományos információk szerzőitől a kereskedő cégekbe befektetőkig mindenkire szüksége van a rendszernek. Az nem állítható, hogy a teljes nyílt hozzáférés megvalósulásáig nem lesznek érdeksérelmek. 
A tudományos információk az egész világon túlnyomórészt közpénz felhasználásával keletkeznek. A közzétételük folyamatában megjelenő magánérdekek mentén sok a hozzáadott érték. A teljes Open Access elérésének folyamatában - magam azt gondolom - külön kell választani az elsődleges közlést attól, amikor az a hozzáadott értékkel együtt jelenik meg (ez utóbbi lehet egy másik, attraktívabb kereső, lehet ismeretterületek, dokumentum-együttesek összekapcsolása, mesterséges intelligencia alkalmazások stb., stb.). Biztosan lesz időszak, amikor csak előbbi lesz elérhető mindenki számára állampolgári jogon, és a hozzáadott értéket kell megfizetni. Maga a köz persze eldöntheti, hogy ez utóbbi finanszírozásából milyen mértékben veszi ki a részét azért, hogy a - mondjuk így - passzív szabad elérés lehetőségét kiegészíti az attraktív elérések szabadságának megteremtésével. 


\section{Open Science \\ NYÍLT TUDOMÁNY MAGYAR SZEMMEL}


A Magyar Tudományos Akadémia Könyvtárának Közleményei Publicationes Bibliothecae Academiae Scientiarum Hungaricae

$45(120)$
UJ SOROZAT

SOROZATSZERKESZTő

GaÁlné Kalydy Dóra 


\section{Open Science \\ NYÍLT TUDOMÁNY MAGYAR SZEMMEL}

Magyar Tudományos Akadémia

KöNYVTÁr ÉS InFORMÁcIÓs KözPONT

BUDAPEST 2021 


\author{
Szerkesztette \\ GaÁlné Kalydy DóRA \\ Anyanyelvi lektor \\ MóNOK MÁRIA \\ Az irodalomjegyzékeket készítette \\ BudAI-KirÁLY TÍmEA \\ Tipográfia és tördelés \\ VAs ViKTória \\ ISBN 978-963-7451-73-7 \\ ISSN 0133-8862 \\ DOI 10.36820/MTAKIK.KOZL.2021.OpenS
}

Felelős kiadó: az MTA Könyvtár és Információs Központ főigazgatója

Nyomta és kötötte az Alföldi Nyomda Zrt., Debrecen

Felelős vezető: GYöRGy GÉzA vezérigazgató

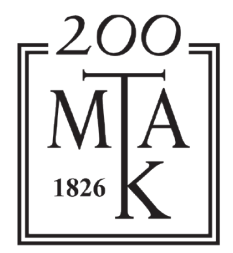

Megjelent a Nemzeti Kulturális Alap támogatásával

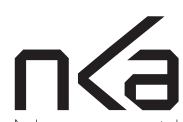

Nemzeti Kulturális Alap 


\section{TARTALOM}

\section{Monok István}

Cui bono, seu cui prodest?

Holl András

A tudományos szakkönyvtárak és a nyílt tudomány

(Open Science)

GaÁlnÉ Kalydy Dóra

A kiadókkal kötött Read and Publish szerződések, és a nyílt hozzáférésű publikálás hazai lehetőségei

Soós SÁndor, Kiss AnNA

Az „Open Access-előnyök" megnyilvánulása

a hazai tudásprodukcióban: bibliometriai hatásvizsgálat

61

\section{GaÁlné Kalydy Dóra}

A közösségi tudomány

\section{Tiberius Ignat}

What motivates us to develop the

Focus on Open Science series?

\section{Hoczopán Szabolcs, Molnár Tamás}

Az egyetemi könyvtárak szerepe a nyílt tudomány

mozgalom elterjesztésében

\section{Holl ANDrás}

Az MTA KIK gyakorlata a nyílt tudomány támogatásában $\quad 161$

A kötetben szereplő tanulmányok szerzői

A Magyar Tudományos Akadémia Könyvtárának

Közleményei, Új Sorozat közelmúltban megjelent kötetei 